\title{
MECHANICAL PROPERTIES OF PARTICLEBOARD PANELS MADE FROM AGRICULTURAL WASTES
}

\author{
Zakia Hussein*, Taha Ashour**, Mervat H. Khalil***, \\ Adel H. Bahnasawy ${ }^{* * * *}$ and Samir A. Ali***
}

\begin{abstract}
The aim of this study is to characterize the mechanical properties of particleboard (tensile strength (TS), compressive strength (CS), modulus of rupture (MOR) and modulus of elasticity (MOE)) as affected by various parameters. The effects of waste type, particleboard density and resin content on the mechanical properties of the particleboards were investigated. Also, the possibility of using treated rice straw to improve the properties of the particleboards was evaluated. The results showed that an improving in the mechanical properties of rice straw particleboards with increasing the density of particleboard and the added resin content in the mixture. While the internal bond (IB) initially increased then decreased with increasing particleboard density. Finally, the MOR and MOE decreased with increasing resin content. Hot-water treatment induced better performance on the properties of particleboards.
\end{abstract}

Keywords: particleboards, rice straw, flax shives, Urea formaldehyde, mechanical properties.

\section{INTRODUCTION}

$\mathrm{H}$ eating costs in the winter and cooling costs in the summer are very high. As building insulation reduces heating costs in the winter and cooling costs in the summer. Therefore, the use of insulation materials has become a necessity. The production of appropriate materials for insulation materials is of great importance.

\footnotetext{
* Demonstrator of Agric. Eng., Fac. of Agric., Benha Univ., Egypt

** Professor. of Agric. Eng., Fac. of Agric., Benha Univ., Egypt.

*** Professor at Institute of building physics and environment, National reserch center of housing and buildings, Cairo, Egypt.

****Professor. of Agric. Eng., Fac. of Agric., Benha Univ., Egypt.

****** Professor. of Agric. Eng., Fac. of Agric., Benha Univ., Egypt.
} 
Insulation materials are usually produced from inorganic materials. In recent years, these materials have been prohibited due to the suspicion of health risks Thus, it is important to investigate organic-based insulation materials. On the other hand, large quantities of agricultural residues are available that have potential alternative uses for some inorganic materials such as particleboard production. Although rice production in Egypt is significant, after the production the rice straw is a serious problem for farmers. Rice straw are cleaned, burned or used for temporary heating purposes. This type of use is causing serious problems to the environment. Consequently, rice straw is the renewable resource that can be utilized as raw materials for making insulated particleboard. Particleboard is one instance from the applications of wood. Particleboard is a panel product manufactured under pressure from particles of wood or other lignocellulosic materials and an adhesive. Particleboard historically has been made with forest products. However, due to government restriction; wildlife protection, and other environmental concerns, the availability of these raw materials has been decreasing. The demand for particleboard products continues to increase, leaving an increasing gap between raw materials and products demand. This researcher will use rice straw as alternative to fill this gap. Rice is the primary food for more than $40 \%$ of the world's population, with about 596 million tons of rice and 570 million tons of rice straw produced annually in the world (Pathak et al., 2006; Mohdy et al., (2009). Currently, 12 million MTs of rice straw is produced annually in Egypt (CAPMAS, 2013), most of which returns back to field by burying or burning, or serves as an on-farm fuel source. Tong et al., (2001) found that Straw is rich in resources, with low density, renewable nature and lustration. Rice straw is an annually renewable agricultural by-product. Its unique characteristics have drawn attention of researchers throughout the world. Particleboard performance is mostly related to the properties of adhesives and their compatibility with fibres. Several types of adhesive resins have been used to make straw particleboard. Ureaformaldehyde (UF) has been the major adhesives for wood-based particleboard. The manufacture of particleboards from eggplant stalks using UF adhesive is technically viable (Guntekin and Karakus 2008). 
Researchers have succeeded in studying some parameters such as resin content, particleboard density and straw treatment to improve the mechanical properties of the particleboard. The mechanical properties of particleboard made of mesquite, salt cedar and date palm were improved as the Urea-formaldehyde (UF) resin content increased from 9 to $11 \%$ (Ashori and Nourbakhsh 2008). The qualities of particleboard were improved as the content of UF resin increased from 7\% to 16\% (Pan $\boldsymbol{e t}$ al., 2007). The mechanical properties of the saline Jose Tall Wheatgrass (JTW) particleboards improved with the increase of particleboard density from 0.71 to $0.75 \mathrm{~g} / \mathrm{cm}^{3}$ (Zheng et al., 2007). Values of the mechanical properties showed that hot-water treatments on RS induced better performance on the obtained composites (Junjun and Chuanhui 2013). Steam and short durations of OA-treatment resulted in significantly improved mechanical properties of UF-bonded rice straw particleboards (Li et al., 2011). The treatment of oil palm particles before board making gives a positive effect by improving the mechanical properties of board. As resulted, the treatment with hot water improved for board properties (Jumhuri et al., 2014). The mechanical properties of the corn-stalkbased fiberboard without adhesive were improved by pretreatment with the white-rot fungus T. hirsute. Pretreatment increased the mechanical properties of the fiberboard (Wu et al., 2011). Because of a little information is available on use of rice straw for particleboard in combination with adhesives and effect of resin content, particleboard density and rice straw treatment on the mechanical properties of particleboard. To achieve that the specific objectives of this work are to utilize rice straw for making insulation particleboards and evaluate the effect of different waste type, resin content, particleboard density and rice straw treatment on the mechanical properties of particleboard.

\section{EXPERIMENTAL PROCEDURES}

\subsection{Materials}

Rice straw was cultivated on the Shubra Millis, Zifta, Al Gharbiyah Governorate, Egypt. At maturity, the straw was harvested and left in the open field for two weeks to dry and then moisture content (MC) of the straw was about 5\%. The commercial UF resin adhesive (65 wt.\% of 
solid content) was used as a composite binder. Ammonium chloride $\left(\mathrm{NH}_{4} \mathrm{Cl}\right)$ solution $(10 \mathrm{wt} . \%)$ was added to the UF as a hardener material. These two materials and flax shives were obtained from Tanta Company of Flax and Oils, Tanta.

\subsection{Sample preparation}

Rice straw was obtained from local farming operation. After received, the rice straw was broken down into different particle sizes from 10-40 $\mathrm{mm}$ using a hammer mill. The hammer milling reduced the straw particles size, and then the straw particles were screened to remove fines and dust from the straw stream. Treatment of rice straw was carried out according to Junjun et al., (2012). A desired amount of straw was sprayed with resin material. After spraying, the straw particles were sufficient mixing for 8 minutes. The mixture was poured into a steel mold placed on a wood board. The steel mold dimensions are 700 x 350 $\mathrm{mm}$. For one layer, it was put into the mould and press by hands for making mat forming. The mould was pulled from around straw particles before primary press. The particleboards were manufactured using a Primary press with a manually controlled hydraulic press system. The time period of press was approximately $2 \mathrm{~min}$. After Primary press, the boards were placed in between the heated platens of the hot press. The platens of the press were heated to a constant temperature of $180{ }^{\circ} \mathrm{C}$ to ensure optimal curing of the resin material. The platens compressed the boards; the load applied to the boards was set to 210 Bar. The total time from the press closing to opening was approximately $12 \mathrm{~min}$. The edges of the particleboard were trimmed with a utility knife. The finished boards were cut to desired length, width and to square the edges.

Different recipes of particleboards with different parameters were prepared for testing. These parameters include resin ratio $(10,12$ and 14 $\%$ ), waste type (rice straw and flax shives), particleboard density $(0.3,0.5$ and $0.7 \mathrm{~g} / \mathrm{cm}^{3}$ ) and straw treatment (hot water and Sodium hydroxide $(\mathrm{NaOH}))$. Different recipes are given in Table (1).

\subsection{Test Procedure}

The particleboard was cut into various specifications according to the ASTM standard method, D1037-06 (American Society of Testing and 
Materials, 2006). Prior to property evaluation, specimens were conditioned for $72 \mathrm{~h}$ in a Fisher-brand Desiccators Cabinet maintained at $65 \% \mathrm{RH}$ and $20 \pm 1^{\circ} \mathrm{C}$ to achieve stable conditions.

Table 1: Recipes of designed particleboards.

\begin{tabular}{ccccc}
\hline \hline Recipes & $\begin{array}{c}\text { Type of } \\
\text { waste }\end{array}$ & $\begin{array}{c}\text { Ratio of } \\
\text { resin }(\%)\end{array}$ & $\begin{array}{c}\text { Density of } \\
\text { Particleboard } \\
\left(\mathbf{g} / \mathbf{c m}^{3}\right)\end{array}$ & $\begin{array}{c}\text { Treatment } \\
\text { of straw }\end{array}$ \\
\hline \hline & Rice straw & 12 & 0.7 & Untreated \\
& & 14 & 0.3 & \\
2 & Rice straw & 12 & 0.5 & Untreated \\
& & & 0.7 & NaOH \\
3 & Rice straw & 12 & 0.5 & Hot water \\
& Rice straw & 12 & & Untreated \\
4 & Flax shives & 12 & 0.5 & Untreated \\
\hline \hline
\end{tabular}

\subsubsection{Flexural strength (Static bending)}

Static bending tests shall be made to determine the flexural properties, such as modulus of rupture (MOR) and apparent modulus of elasticity (MOE). Static bending tests were conducted on samples in accordance with ASTM D1037-06 section 9. The test involves utilizing a three-point bending test to obtain the modulus of elasticity (MOE) and the modulus of rupture (MOR) for the particleboards (Figure 1). The flexural strength was measured by using specimens with dimension of $530 \times 76 \times 20 \mathrm{~mm}$ (rectangular pieces). Each flexural strength result was the average of strength for three specimens as replicates. Each sample was loaded with a central loading nose and two support noses, each having a radius of 25.4 $\mathrm{mm}$. The two support noses were placed such that the span between them was as suggested in the ASTM D1037, 24 times the nominal board thickness. Loading of the samples was achieved by lowering the central loading nose at a constant crosshead rate determined by the sample geometry, given by equation (1):

$$
N=\frac{z L^{2}}{6 d}
$$


where $N$ is the crosshead rate $(\mathrm{mm} / \mathrm{min}), L$ and $d$ are the length and thickness of specimen $(\mathrm{mm})$, respectively and $z$ is the unit rate of fibre strain of outer fibre length per minute $(z=0.005$ according to ASTM D1037).

The maximum load achieved during the test and the corresponding vertical deflection were recorded in order to calculate the MOE and MOR of the samples. The modulus of rupture and the modulus of elasticity are calculated by Eqs. (2) and (3), respectively:

$$
\begin{aligned}
& \text { MOR }=\frac{3 P_{\max } L}{2 b d^{2}} \\
& M O E=\frac{L^{3}}{4 b d^{3}} \frac{\Delta p}{\Delta y}
\end{aligned}
$$

Where MOR is the modulus of rupture (MPa), $P_{\max }$ is the maximum load $(\mathrm{N}), \mathrm{b}$ is the width of specimen $(\mathrm{mm}), M O E$ is the modulus of elasticity (MPa) and $\frac{\Delta p}{\Delta y}$ is the slope of the straight-line portion of the load deflection curve $\left(\mathrm{N} / \mathrm{mm}\right.$ ) (slope between $10 \%$ and $40 \%$ of $P_{\max }$ as suggested in note 16 of ASTM D1037).

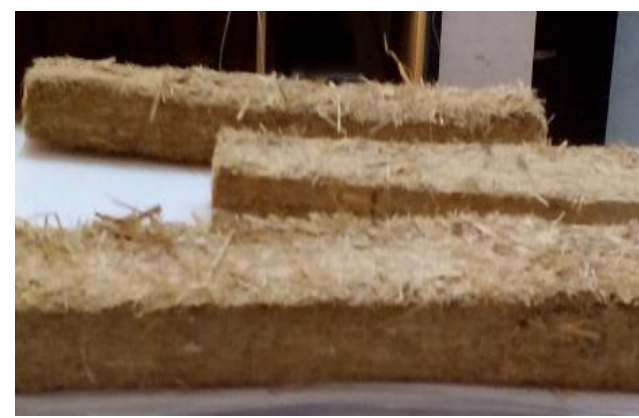

a)

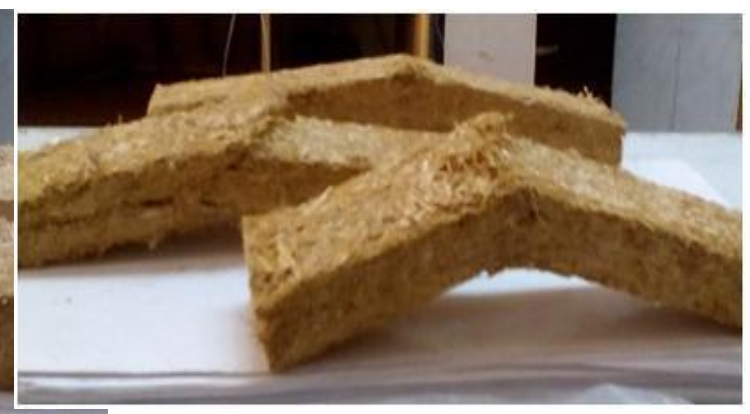

b)

Fig. 1: samples for static bending test, a) before the test. b) after the test.

\subsubsection{Internal Bond strength (Tension Perpendicular to Surface)}

The tension test perpendicular to the surface shall be made to determine cohesion of the panel in the direction perpendicular to the plane of the panel. Internal bond was measured according standard of ASTM D103706 section 11. In the standard test for IB, the internal bond strength was measured by using specimens with dimension of $50 \times 50 \times 20 \mathrm{~mm}$ (square 
pieces). Each internal bond strength result was the average of strength for three specimens. Samples were adhered to the faces of aluminium loading blocks by first heating the loading blocks and melting a hot melt adhesive on the face, then placing individual samples between two loading blocks and letting the adhesive set in room temperature with no pressure applied to the samples. A minimum of $24 \mathrm{~h}$ was allowed to pass after adhering to the loading blocks before samples were tested. Each sample was loaded into the testing fixture by placing the loading blocks such that the slots in each block made sufficient contact with the fixture arms (Fig. 2). Samples were loaded perpendicular to the panel face until specimen failure occurred. The rate of loading was kept at a constant 1.6 $\mathrm{mm} / \mathrm{min}$ rather than keeping the speed of testing at a rate of $0.08 \mathrm{~cm} / \mathrm{cm}$ as was specified in ASTM D1037. The maximum load achieved during the test before specimen failure occurred was recorded and used to calculate the internal bond strength, where the internal bond strength is calculated as follows:

$$
I B=\frac{P_{\max }}{b L}
$$

where IB is the internal bond strength (MPa).

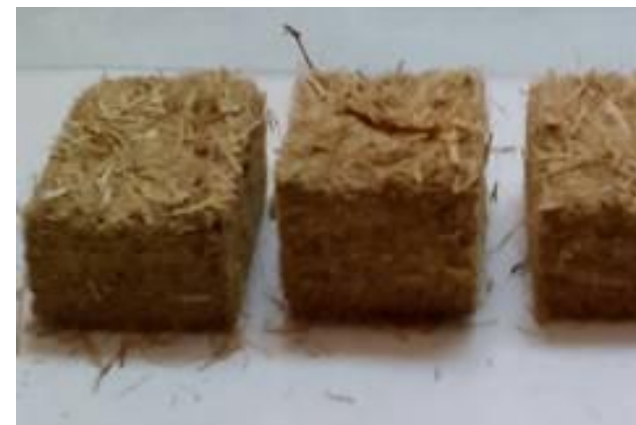

a)

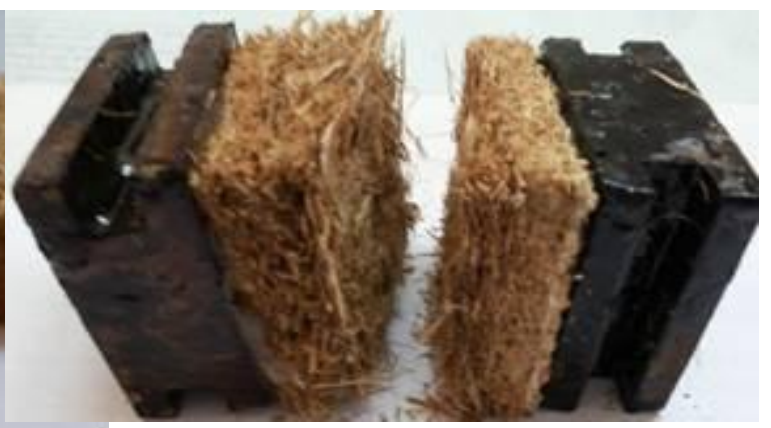

b)

Fig. 2: samples for tension test, a) before the test. b) after the test.

\subsubsection{Compression strength}

The compression test shall be made to determine the compressive strength in the plane of the panel. Compression was measured according standard of ASTM D1037-06 section 12. The compression strength was measured by using specimens with dimension of $102 \times 25 \times 20 \mathrm{~mm}$ 
(rectangular pieces). Each compression strength result was the average of strength for three specimens. The specimen was entered carefully through a spherical loading blocks in the testing machine in a vertical plane for unsupported $(102 \mathrm{~mm})$ specimen. The specimen was loaded parallel to the panel face until specimen failure occurred. The rate of loading was kept at a constant $0.5 \mathrm{~mm} / \mathrm{min}$ rather than keeping the speed of testing at a rate of $0.005 \mathrm{~mm} / \mathrm{mm}$ as was specified in ASTM D1037. The maximum load achieved during the test before specimen failure occurred was recorded and used to calculate the compression strength, where the compression strength is calculated as follows:

$$
C S=\frac{P_{\max }}{b d}
$$

where CS is the compressive strength (MPa).

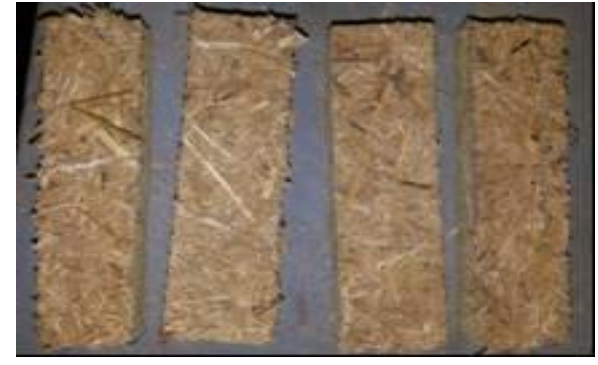

a)

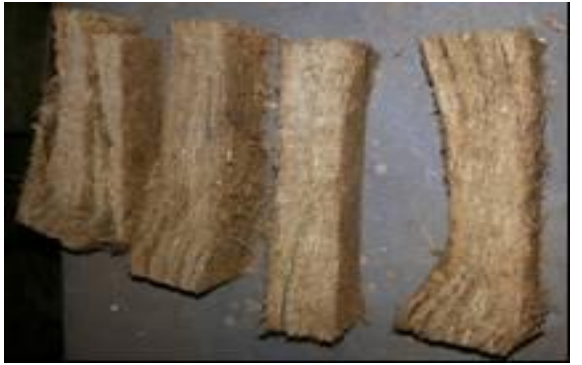

b)

Fig. 3: Compressive strength test samples, a) before the test. b) after the test.

\section{RESULTS AND DISCUSSION}

3.1. Effect of waste type on the mechanical properties of particleboard

\subsubsection{Flexural strength (Static bending)}

Fig. 4 illustrates the modulus of rupture (MOR) and modulus of elasticity (MOE) as a function of waste type. The results reveal that, boards made with flax shives exhibited superior bending properties compared to the rice straw particles. For example, the maximum values of the MOR and MOE were $13.85 \mathrm{MPa}$ and $1722 \mathrm{MPa}$ for flax shives, respectively, while the values for rice straw were $1 \mathrm{MPa}$ and $181.9 \mathrm{MPa}$, respectively. The results also proved that MOR and MOE values for flax shives were 
higher than rice straw. This may be due to use of light particles improve bending properties of particleboard due to high compaction ratio. These results trend agreed with those obtained by Tabarsa et al., (2011).

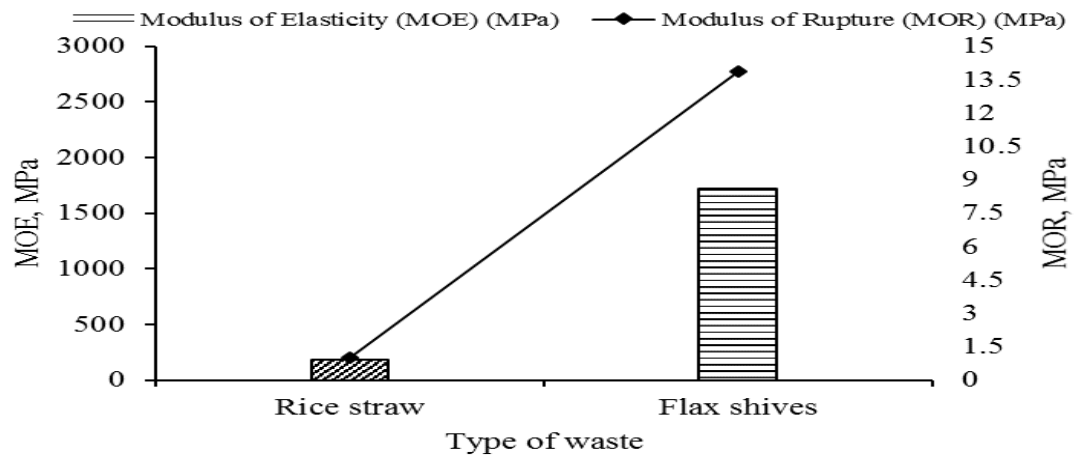

Fig. 4: The effect of waste type on bending properties of particleboard.

\subsubsection{Internal Bond strength}

The results are shown in Fig. 5 demonstrate the influence of waste type on the internal bond property of experimental rice straw particleboard. Bending properties such as MOR and MOE, boards made with flax shives showed higher internal bond than those made from rice straw particles. The internal bond value increases from 0.02 to $0.6 \mathrm{MPa}$. The possible reason proposed for this kind of behavior may be due to the high compaction of flax shives furnish which caused faster heat transfer to the core layer resulted more curing of resin. These results trend agreed with those obtained by Tabarsa et al., (2011).

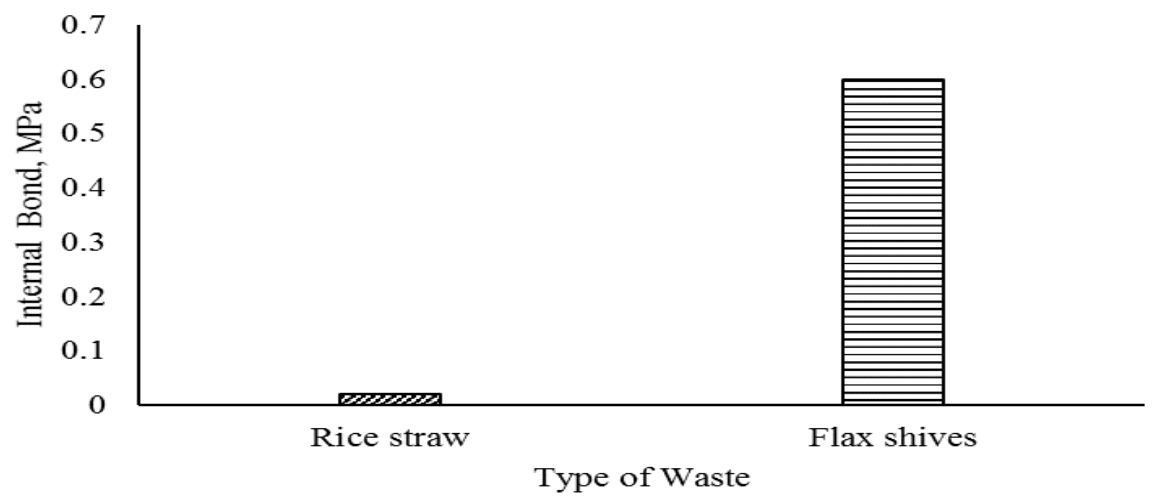

Fig. 5: Internal bond of particleboard as a function of waste type. 


\subsubsection{Compression strength}

The particleboard made from rice straw particles is much weaker in compression strength than that from flax shives as shown in Fig. 6 . Where, the compression strength value of untreated rice straw is $1.7 \mathrm{MPa}$ and is $12.4 \mathrm{MPa}$ for untreated lax shives. This was due to the particleboard prepared with flax shives had smaller size than that rice straw particles, which increase the compaction of flax shives particleboard. The mechanically split of flax shives result in the best compression strength of composites compared to rice straw. This is may be due to the increasing of surface area of flax shives compared with rice straw. These results trend agreed with those obtained by Yi et al., (2010).

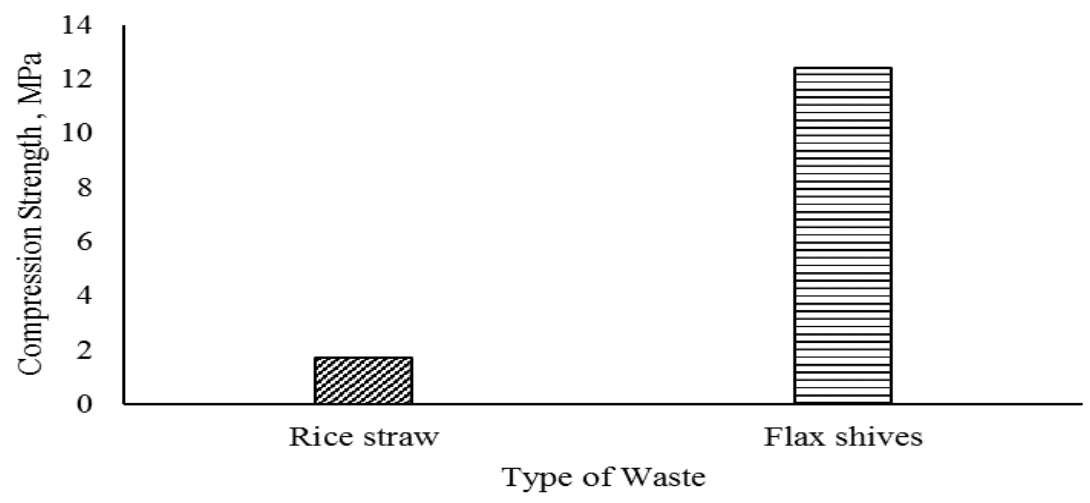

Fig. 6: The influence of waste type on Compression strength of particleboard.

\subsection{Effect of particleboard density on the mechanical Properties}

\subsubsection{Flexural strength (Static bending)}

The bending properties of the particleboards were strongly dependent on the density, and two regions of MOR and MOE are shown in Figs 7. Increased density resulted in significant improvement of the bending properties. The higher density of the particleboards generates a higher number of contact points (inter-bonding between fibers), which consequently improve the bending strength. For particleboard produced at the lower density had MOR value reached $0.6 \mathrm{MPa}$, the corresponding MOE value reached $91.8 \mathrm{MPa}$. Higher density in the produced particleboard resulted in improved bending properties, causing MOR to increase to $1.95 \mathrm{MPa}$ and the corresponding $\mathrm{MOE}$ value to reach 
approximately $244 \mathrm{MPa}$. These results agreed with those obtained by Khristova et al., (1996) and Zheng et al., (2007).

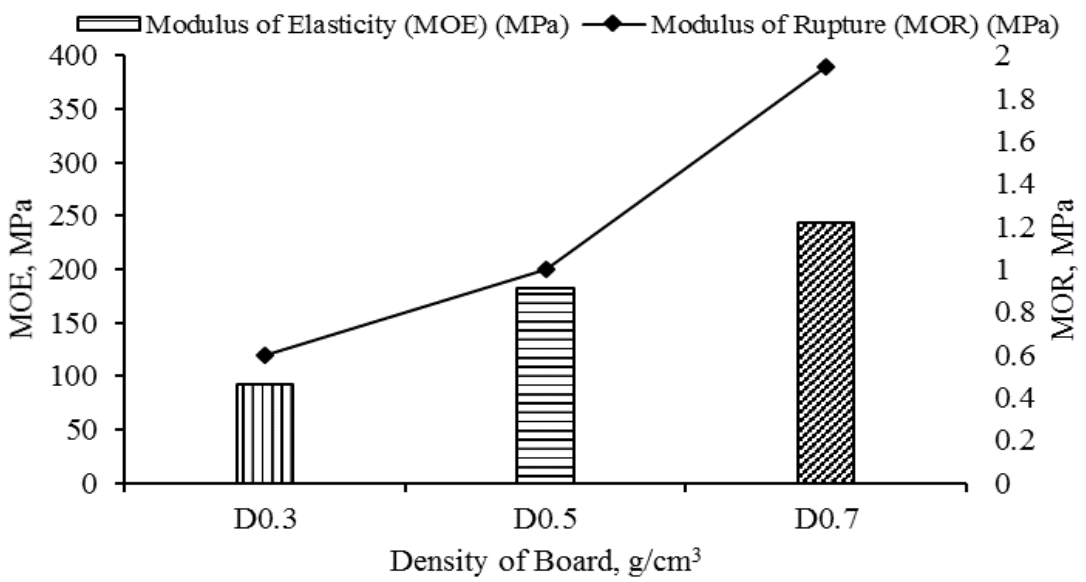

Fig. 7: The effect of board density on bending properties of particleboard.

\subsubsection{Internal Bond strength}

The results presented in Fig. 8 demonstrate the influence of board density on the internal bond property of experimental rice straw particleboard. The results mentioned that internal bond increased and then decreased with increasing of particleboard density, and reached to the peak value at particleboard density of $0.5 \mathrm{~g} / \mathrm{cm}^{3}$. The internal bond property decreased with increasing of particleboard density above $0.5 \mathrm{~g} / \mathrm{cm}^{3}$. At a board density of $0.3-0.5 \mathrm{~g} / \mathrm{m}^{3}$, the internal bond significantly increased from 0.003 to $0.02 \mathrm{MPa}$. At a board density of $0.5-0.7 \mathrm{~g} / \mathrm{m}^{3}$, the internal bond slightly decreased from 0.02 to $0.008 \mathrm{MPa}$. This could be accounted for looser internal structure, more moisture content of particleboard and weakened adhesive solidification, and the internal bond property was lower at density below $0.5 \mathrm{~g} / \mathrm{cm}^{3}$. When density was $0.5 \mathrm{~g} / \mathrm{cm}^{3}$, moisture content was appropriate, adhesive material diffuses uniformly and could glue the rice straw completely, internal bond strength reached the peak value. The internal bond property decreased with increasing of density above $0.5 \mathrm{~g} / \mathrm{cm}^{3}$, this was due to more compact internal structure and more difficult adhesive material diffusion. These results trend are similar to those obtained by Junjun et al., (2012). 


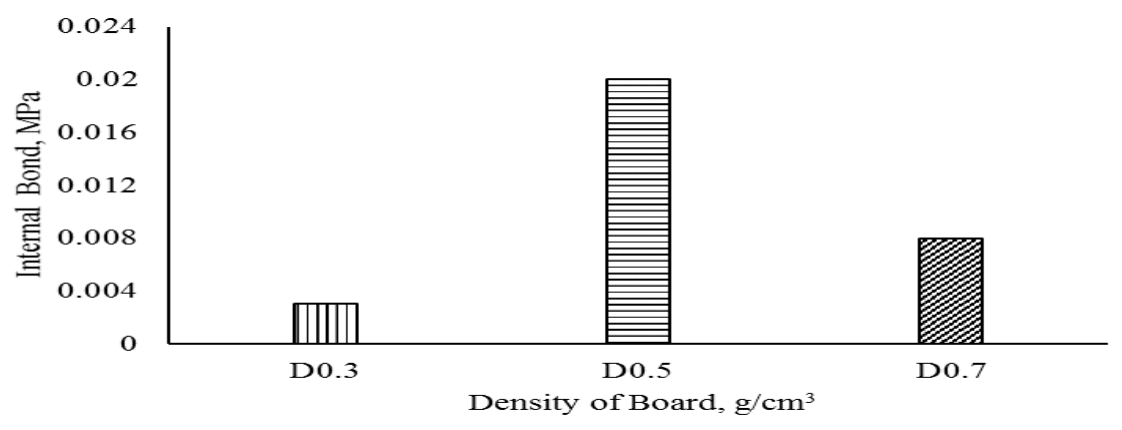

Fig. 8: Internal bond of particleboard as a function of board density.

\subsubsection{Compression strength}

Fig. 9 plots the effect of board density on the compression strength of rice straw particleboards. Increasing of density of particleboard positively affects the compression property, which compression strength increased with increasing of particleboard density. The high density of particleboard showed high compressive strength due to their low porosity. It appears that for the compression strength was increased from 0.7 to $1.7 \mathrm{MPa}$ with increasing the board density from 0.3 to $0.5 \mathrm{~g} / \mathrm{cm}^{3}$. The peak value of compressive strength reached $2.5 \mathrm{MPa}$ at particleboard density of $0.7 \mathrm{~g} / \mathrm{cm}^{3}$. These results trend agreed with those obtained by Donghai and Xiuzhi (2002).

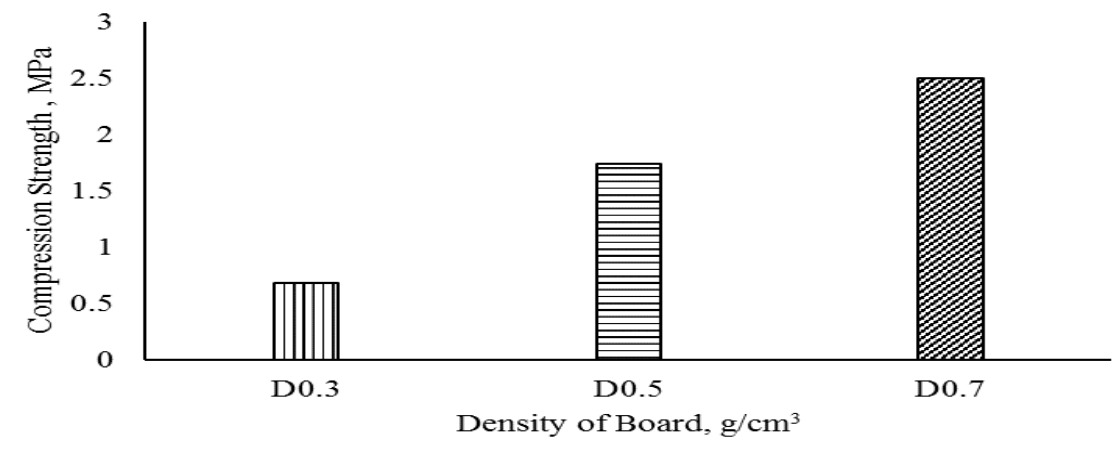

Fig. 9: The effect of board density on compression strength of particleboard.

\subsection{Effect of resin content on the mechanical Properties of particleboard}

\subsubsection{Flexural (Static bending)}

Fig. 10 presents the modulus of rupture (MOR) and modulus of elasticity (MOE) as a function of resin content. The bending properties of the 
particleboards were strongly dependent on the resin content, and two regions of MOR and MOE are shown in Figs. 13. The results revealed that decreasing of resin content lead to significant improvement of the bending properties. The lower resin content of the particleboards generates a higher number of contact points (inter-bonding between fibers), which consequently improve the bending strength. For particleboard produced at the higher resin content (14\%) had MOR value reached 1.3 $\mathrm{MPa}$, the corresponding MOE value reached 213.6 MPa. Lower resin content $(10 \%)$ in the produced particleboard resulted in improved bending properties, causing MOR to increase to $2.1 \mathrm{MPa}$ and the corresponding MOE value to reach approximately $344.97 \mathrm{MPa}$. The bending properties decreased with increasing of resin content, this was due to increase solidification of particleboard.

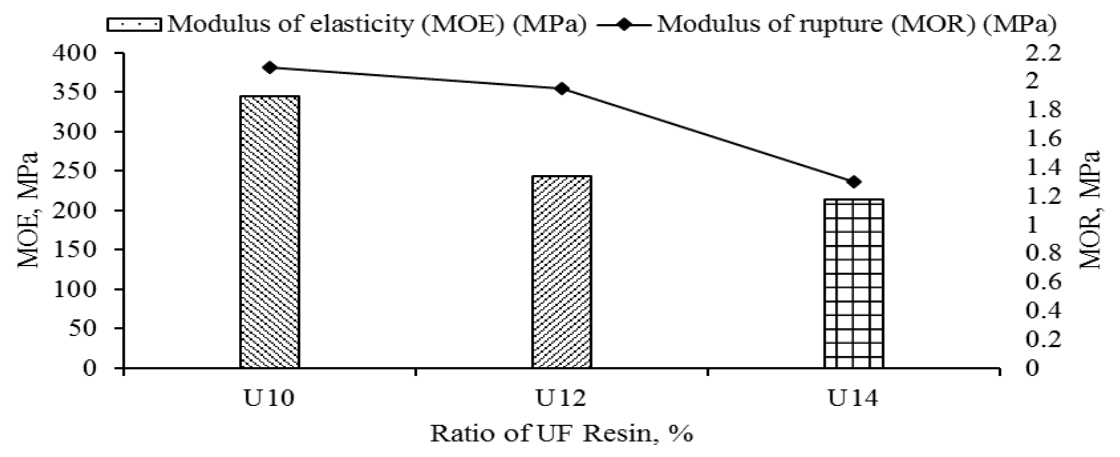

Fig. 10: Bending properties of particleboard as a function of resin ratio of Urea formaldehyde.

\subsubsection{Internal bond strength}

Fig. 11 shows a definitive relationship between the resin content of the produced particleboard and internal bond property. While, Increasing of UF resin ratio in the produced particleboard gives a positive influenced by improving the internal bond property of particleboard. Additionally, increasing the resin content of the produced particleboard from $10 \%$ and $12 \%$ to $14 \%$ improved the internal bond significantly. For example, the internal bond value of particleboards at the lower resin content was $0.002 \mathrm{MPa}$, whereas that of particleboards produced at the higher resin content was $0.016 \mathrm{MPa}$. These results trend agreed with those obtained by (Guntekin and Karakus 2008). 


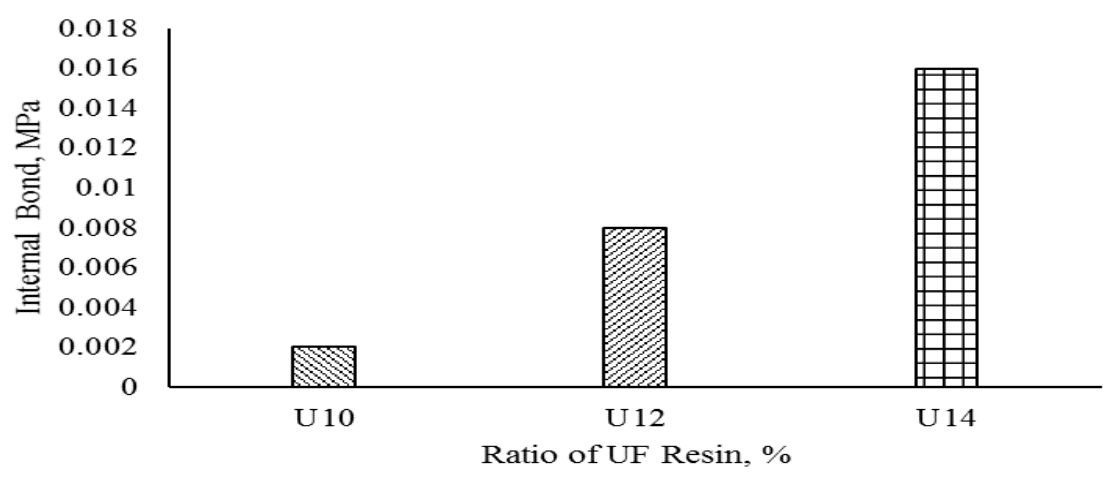

Fig. 11: The influence of resin ratio of Urea formaldehyde on internal bond of particleboard.

\subsubsection{Compression strength}

The compression strength was plotted as a function of resin content for all produced particleboard in Fig. 12. The results reveal that, the influence of resin content on compression strength is very important. While Increasing of UF content lead to improve compression strength of the produced particleboard. At particleboard density $0.7 \mathrm{~g} / \mathrm{cm}^{3}$, increasing the resin content from $10 \%$ to $14 \%$ lead to increase the compression strength from 1.55 to $4.46 \mathrm{MPa}$.

A linear regression was made to obtain a relationship between the compressive strength (CS) and the resin ratio of UF as follows:

$C S=1.458 R_{C}-0.0753 \quad\left(\mathrm{R}^{2}=0.963\right)$

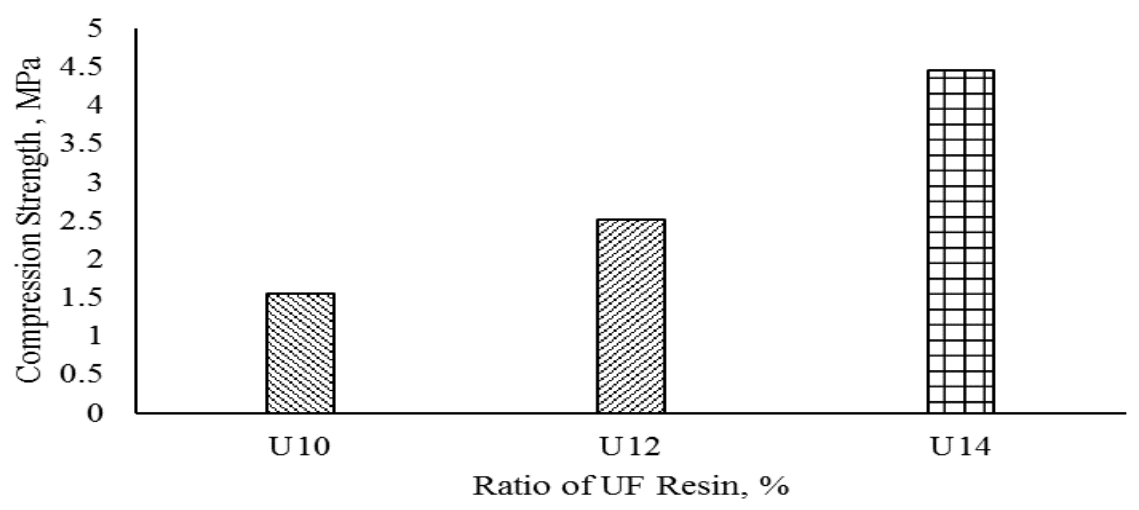

Fig. 12: Compression strength of particleboard as a function of resin ratio of Urea formaldehyde. 


\subsection{Effect of treated straw on the mechanical Properties of particleboard}

\subsubsection{Flexural (Static bending)}

Fig. 13 presents the bending properties modulus of rupture (MOR) and modulus of elasticity (MOE) as a function of chemical treatment of straw. The bending properties of the particleboards were strongly dependent on the chemical treatments of straw, and two regions of MOR and MOE are shown in Figs. 16. For particleboard made from untreated straw had MOR value reached $1 \mathrm{MPa}$, while the MOE value reached 181.9 $\mathrm{MPa}$. Particleboard made from $\mathrm{NaOH}$ treated lead to improve bending properties, while MOR increase to $2.1 \mathrm{MPa}$ and the corresponding MOE value to reach approximately $221 \mathrm{MPa}$, while particleboard from hot-water treated resulted in improved MOR, causing to increase to $2.8 \mathrm{MPa}$ and worse MOE, causing to decrease to 163.6 MPa.

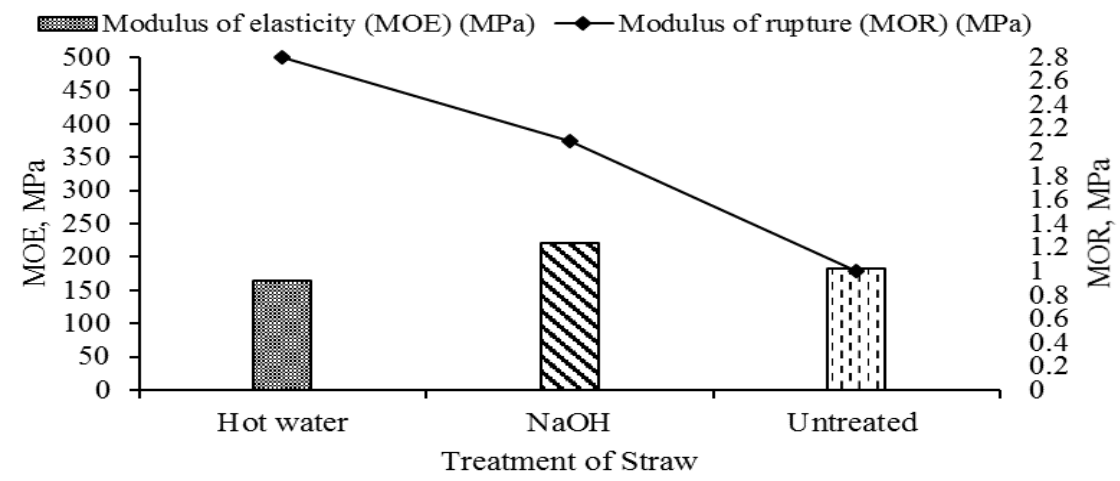

Fig. 13: The effect of treated rice straw on bending properties of particleboard.

\subsubsection{Internal bond strength}

Fig. 14 shows the effect of treated straw on internal bond strength of rice straw particleboard made by using $12 \%$ UF resin. IB value showed that hot-water treatments on RS induced better performance on the produced particleboards. In contrast, $\mathrm{NaOH}$ treatments on RS reduced IB of the particleboard slightly. It appears that for particleboard made from hot water-treated straw, the internal bond strength initially increases from 0.02 to $0.045 \mathrm{MPa}$ and then decreases to $0.005 \mathrm{MPa}$ when the straw treatment changes to $\mathrm{NaOH}$ treated straw. This could be attributed to the 
higher content of silica, which existed in the form of non-polar surface structure, resisting the adsorption of rice straw with UF adhesive. Hotwater treatments on RS removed the silica and wax on the surface partly, which reduced the contact angle on straw surface and increased infiltration with UF adhesive, making higher interface bonding strength between rice straw and adhesives. These results trend agreed with those obtained by (Junjun and Chuanhui 2013).

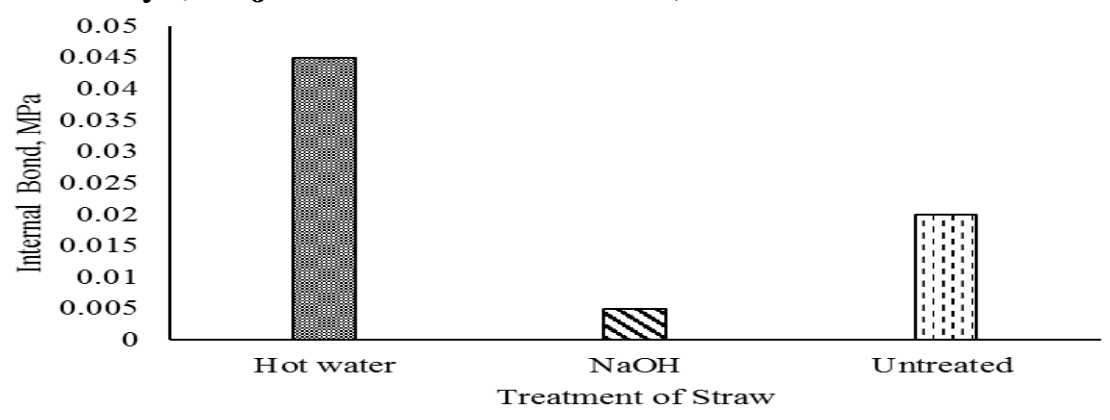

Fig. 14: Internal bond of particleboard as a function of treated rice straw.

\subsubsection{Compression strength}

Fig. 15 shows the effect of pre-treatment on the compression strength of rice straw particleboards. In comparison with the rice straw untreated particleboard, a significant improvement was observed in hot water treated rice straw particleboards, where compression strength increased from 1.7 to $3.4 \mathrm{MPa}$. For the $\mathrm{NaOH}$ treated rice straw particleboards, the compression strength increased to $1.8 \mathrm{MPa}$. The increase of compression strength could be mainly due to the extraction of hemicelluloses, wax like substances, and other non-polar extractives from rice straw in pre-treatment resulting in improved compatibility between rice straw and UF resin. These results clearly indicate that the addition of $\mathrm{NaOH}$ in pre-treatment has a negative effect on comparison strength of particleboards compared to hot water treatment. The results revealed that the compression strength of particleboards decreased after the $\mathrm{NaOH}$ pre-treatment. This could be caused by the $\mathrm{NaOH}$ treatment may be lower the $\mathrm{pH}$-value of particles because of residual $\mathrm{NaOH}$ on the surface and interior of rice straw particles, which lead to a pre-curing of the UF resin. 


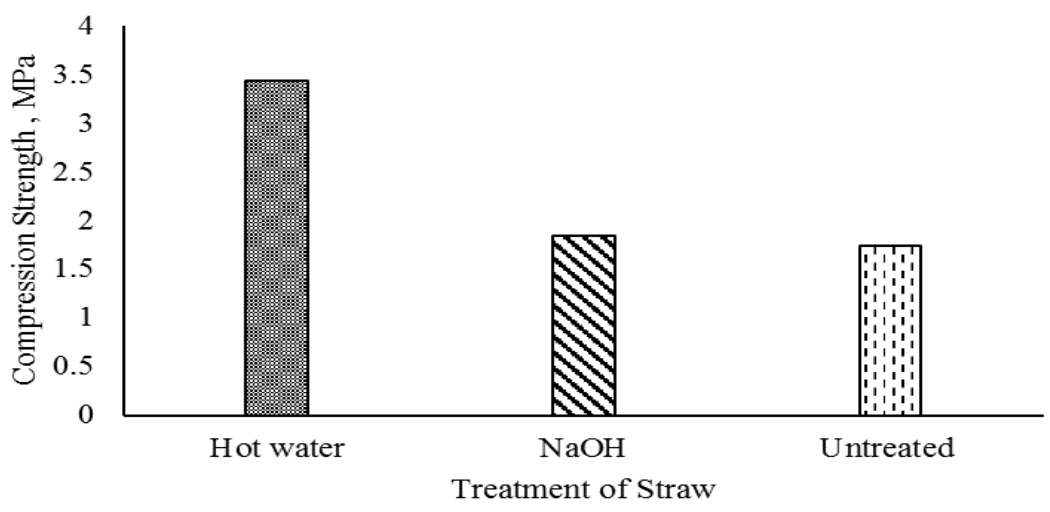

Fig. 15: The effect of treated rice straw on compression strength of particleboard.

\section{CONCLUSIONS AND RECOMMENDATIONS}

Particleboards made with flax shives had superior properties compared to the rice straw particles. The mechanical properties of the particleboards increase with increasing resin content except for the MOR and MOE decreases with increased resin content, and reached to the peak value at resin content of $10 \%$. Additionally, increasing particleboard density significantly improved the mechanical properties of the particleboards except for the IB initially increases then decreases with increased particleboard density, and reached the peak value at particleboard density of $0.5 \mathrm{~g} / \mathrm{cm}^{3}$. Maximum mechanical strength was obtained at $0.7 \mathrm{~g} / \mathrm{cm}^{3}$ particleboard density and at $14 \%$ resin content with UF. Finally, rice straw treated by hot water induced better performance on the mechanical properties of produced particleboards except for modulus of elasticity (MOE) which that reach to peak value with $\mathrm{NaOH}$ treatment.

\section{ACKNOWLEDGEMENTS}

The authors express their sincere thanks to all staff members in Tanta Company of Flax and Oils, Tanta, Al Gharbiyah Governorate, Egypt for providing facilities during preparation of the specimens and the Egyptian Organization for Standardization and Quality (EOS), Cairo, Egypt for reducing costs of the tests. 


\section{REFERENCES}

Ashori, A., and A. Nourbakhsh. 2008. Effect of press cycle time and resin content on physical and mechanical properties of particleboard panels made from the underutilized low-quality raw materials. Industrial Crops and Products 28:225-230.

ASTM. 2006. Standard Test Methods for Evaluating Properties of Wood-Base Fiber and Particle Panel Materials: American Society of Testing and Materials, D1037-06 section 9, 11, 12.

Central Agency for Public Mobilization and Statistics (CAPMAS), Agricultursl sector. 2013. Annual bulletin for statistics of the waste and recycling rice straw. In; http//www.capmas.gov.eg. .

Donghai, W., and S.S. Xiuzhi. 2002. Low density particleboard from wheat straw and corn pith. Industrial Crops and Products 15.

Guntekin, E., and B. Karakus. 2008. Feasibility of using eggplant (Solanum melongena) stalks in the production of experimental particleboard. Industrial Crops and Products 27:354-358.

Junjun, L., J. Chanjuan, and H. Chunxia. 2012. Flexural Properties of Rice Straw and Starch Composites. AASRI Procedia 3:89-94.

Junjun, L., and H. Chuanhui. 2013. Biodegradable Composites from Rice Straw and Cornstarch Adhesives. Advance Journal of Food Science and Technology 5: 41-45.

Jumhuri, N., R. Hashim, O. Sulaiman, W.N.A. Wan Nadhari, K.M. Salleh, I. Khalid, N.I. Saharudin, and M.Z. Razali. 2014. Effect of treated particles on the properties of particleboard made from oil palm trunk. Materials \& Design 64:769-774.

Khristova, P., N. Yossifov, and S. Gabir. 1996. Particle board from sunflower stalks: preliminary trials. Bioresource Technology 58:319-321. 
Li, X., Z. Cai, J.E. Winandy, and A.H. Basta. 2011. Effect of oxalic acid and steam pretreatment on the primary properties of UFbonded rice straw particleboards. Industrial Crops and Products 33:665-669.

Mohdy, F.A., Abdel, E.S., Ayana, Y.M., Sawy, S.M., 2009. Rice straw as a new resource for some beneficial uses. Carbohydrate Polymers 75, 44-51.

Pathak, H., Singh, R., Bhatia, A., Jain, N., 2006. Recycling of rice straw to improve wheat yield and soil fertility and reduce atmospheric pollution. Paddy and Water Environment 4, 111117.

Pan, Z., Y. Zheng, R. Zhang, and B.M. Jenkins. 2007. Physical properties of thin particleboard made from saline eucalyptus. Industrial Crops and Products 26:185-194.

Tabarsa, T., S. Jahanshahi, and A. Ashori. 2011. Mechanical and physical properties of wheat straw boards bonded with a tannin modified phenol-formaldehyde adhesive. Composites Part B: Engineering 42:176-180.

Tong, J., Y, Ma., and L, Ren. Naturally biological materials and their tribology: a review [J].Tribology, 2001, 21(4):315-320.

Wu, J., X. Zhang, J. Wan, F. Ma, Y. Tang, and X. Zhang. 2011. Production of fiberboard using corn stalk pretreated with whiterot fungus Trametes hirsute by hot pressing without adhesive. Bioresource Technology 102:11258-11261.

Yi, Z., H. Shah, and Y. Yiqi. 2010. Lightweight composites from long wheat straw and polypropylene web. Bioresource Technology 101:2026-2033.

Zheng, Y., Z. Pan, R. Zhang, B.M. Jenkins, and S. Blunk. 2007. Particleboard quality characteristics of saline jose tall wheatgrass and chemical treatment effect. Bioresource Technology 98:13041310 . 


\section{الملخص العربيى}

\section{الخصائص الميكانيكية للألواح الحبيية المصنوعة من المخلفات الزراعية}

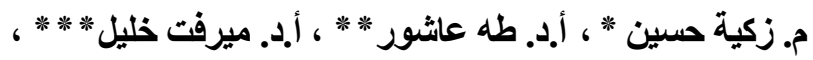

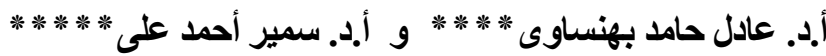

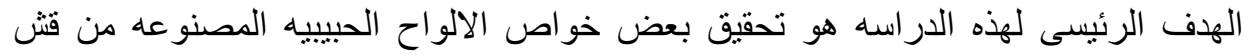

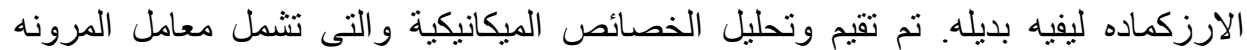
ومعامل الكسر وقوة التر ابط الداخلى وقوه الضغط كدالة فى جميع المتغير ات. شملت متغير اته

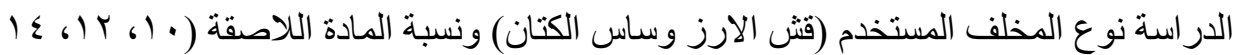

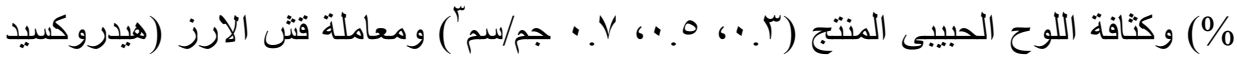
الصوديوم، الماء الساخن) و التى اثرت معنويا فى خصائص الألواح الحبيبيه و النتائج المتحصل وله عليها يمكن تلخيصها كالتالى:

ـ الألواح الحبيييه المصنوعه من ساس الكتان لها خصائص ميكانيكية فائقه مقارنة بتلك

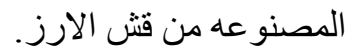

- بزيادة كمية المادة اللاصقة تزداد الخصائص الميكانيكية للالواح الحبيبية فيماعدا معامل

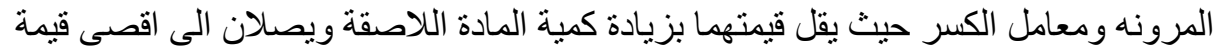
لهما عند كمية مادة لاصقة • 1 \% و ومن ناحية اخرى تحسنت الخصائص المبكانيكية للالواح

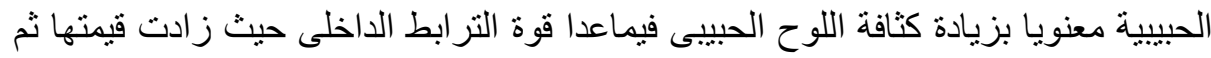

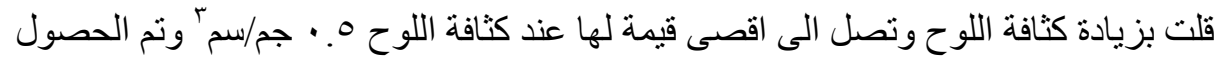

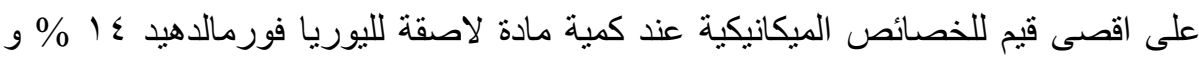

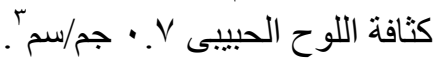
ـ احدثت معالجه قش الارز بالماء الساخن اداء افضل على الخصائص الميكانيكية للالواح

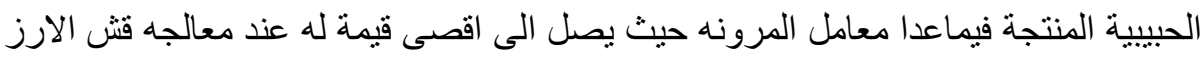

$$
\text { بهيدروكسيد الصوديوم. }
$$

الكلمات الدالة: الالواح الحبييية، قش الارز، ساس الكتان، بيوريا فورمالدهبد، الخصائص المبكانبكبة.

* معيدة، قسم هندسة النظم الزر عية و الحيوية، كلية زر اعة مشتهر، جامعة بنها.

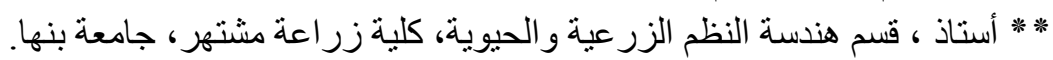
** * أستاذ ورئيس قسم فيزياء المنشأت ، معهد بحوث الاسكان و البناء، القاهرة.

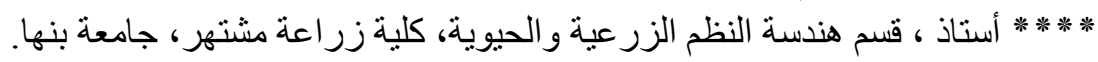
******* **تاذ ، قسم هندسة النظم الزر عية والحيوية، كلية زر اعة مشتهر ، جامعة بنها. 